\title{
REKONSTRUKSI MAKNA \\ PERCERAIAN PERSPEKTIF MASYARAKAT MUSLIM DI KABUPATEN MALANG
}

\author{
Dakwatul Chairah \\ Universitas Islam Negeri Sunan Ampel Surabaya, Indonesia \\ E-mail: dakwatul123@gmail.com
}

\begin{abstract}
This article explores the reconstruction of divorce in the understanding of Muslim community in Malang. Marriage in Islam is not only a civil bond, but also as a religious attachment that contains the values of worship. However, many Muslims fail to defend their marriage. Divorce at Religious Court of Malang district is recorded as very high in East Java. The divorce rate in the region of South Malang is the highest, with labor women as the majority population. They looked at divorce as the only way out to end the marriage. Divorce begins with conflicts, disputes and quarrels which negate the hope to live in harmony again in the household. The solution is understood by most of them as a normal thing that does not need to worry. These perceptions arise because of their lack of knowledge about the meaning of marriage and the danger of divorce with all its consequences. Infact, divorce can result in consequences which disturb the emotion of women and their social and economic conditions as the single parent.
\end{abstract}

Keywords: Divorce; women; Muslim community in Malang.

\section{Pendahuluan}

Perkawinan dalam Islam ditempatkan pada posisi sangat penting bukan hanya sebagai kontrak keperdataan biasa, tetapi juga sebagai tindakan yang bernilai ibadah. ${ }^{1}$ Namun, banyak umat Islam yang gagal mencegah terjadinya perceraian. Menurut Hilman Hadikusuma, ${ }^{2}$ perceraian merupakan ketetapan pemutusan ikatan lahir batin antara seorang pria dengan seorang wanita sebagai suami istri akibat gagalnya

\footnotetext{
${ }^{1}$ Ahmad Rofiq, Hukum Islam di Indonesia (Jakarta: PT.Raja Grafindo Persada, 1995), 60.

2 Hilman Hadikusuma, Hukum Perkawinan Indonesia Menurut Perundangan, Hukum Adat, Hukum Agama Hindu-Islam (Bandung: Mandar Maju, 1990), 160.
} 
tujuan perkawinan karena perbuatan manusia. Padahal Nabi menyatakan, abghad al-ḥalâl ilâ Allah al-talâq (perbuatan halal yang paling dibenci oleh Allah adalah talak). ${ }^{3}$

Dalam perkembangannya memang terdapat fakta yang menunjukkan bahwa perceraian telah menjadi realitas dalam kehidupan Muslim yang angkanya kian meningkat. Hasil penelitian Mark Cammack menunjukkan bahwa pada tahun 1950-an angka perceraian di Asia Tenggara termasuk Indonesia tergolong tertinggi di dunia. Pada dekade itu, dari 100 perkawinan, 50 di antaranya berakhir dengan perceraian. Pada tahun 2009, perceraian mencapai 250 ribu lebih tinggi dari tahun 2008 yang berkisar 200 ribu kasus. Ironisnya, $70 \%$ dari kasus perceraian yang diajukan adalah cerai gugat. ${ }^{4}$

Menurut Syamsul Falah, wakil Ketua Pengadilan Tinggi Agama Surabaya bahwa dari data kasus perceraian yang ditangani Pengadilan Agama di $38 \mathrm{Kab} /$ Kota di Jawa Timur tercatat sebanyak 95.925 kasus dengan rincian 18,037 kasus sisa tahun 2010 dan 77.888 kasus tahun 2011. Perkara yang diputus 74.858 kasus dan sisanya tinggal 21.067 kasus. Menurutnya, mayoritas kasus perceraian di Jawa Timur diajukan melalui cerai gugat yaitu sebanyak 40.091 kasus atau sekitar 62 persen. Sedangkan perceraian atas inisiatif suami hanya 21.249 kasus.

Dari 38 Pengadilan Agama di Jawa Timur, PA Kabupaten Malang menempati urutan pertama dalam menangani kasus perceraian, yakni 7.479 kasus, disusul PA Kabupaten Banyuwangi 6.794 kasus, PA Kota Surabaya dengan 6.529 kasus, PA Kabupaten Jember dengan 4.609 kasus dan PA Kabupaten Blitar dengan 34.609 kasus. ${ }^{5}$ Sedangkan PA terendah pertama dalam menangani kasus perceraian adalah PA Kota Kediri sebanyak 771 kasus, disusul oleh PA Kabupaten Probolinggo sebanyak 530 kasus, PA Kangean sebanyak 528 kasus, PA Kabupaten Madiun sebanyak 451 kasus dan PA Bawean sebanyak 189 kasus.

Tingginya angka kasus perceraian di PA Kabupaten Malang didominasi oleh kasus cerai gugat yang diajukan oleh istri yang bekerja di luar negeri. Menurut Agus Azam Aulia, rata-rata yang mengajukan gugat cerai adalah warga pedesaan Kabupaten Malang yang bekerja sebagai

3 Muhammad b. Ismâ'îl b. Ṣalâh b. Muhammad al-Husaynî al-Kahlânî al-Ṣan'ânî, Subul al-Salâm, Vol. 3 (Kairo: Dâr Ihyâ’ al-Turath al-'Arabî, 1960), 168.

${ }^{4}$ Ayuningtyas Sekar dkk., Perceraian: Makalah Psikologi Seks dan Perkawinan (Surakarta: Universitas Sebelas Maret, t.th.). Mark Cammack adalah guru besar dari Southwestern School Law-Los Angeles, USA.

${ }^{5}$ http:// www.surabayapost.co.id. Diakses tanggal 20 Februari 2017. 
$T K W .^{6}$ Pernyataan ini dibenarkan oleh Siti Romiyati yang menjabat sebagai wakil panitera PA Kabupaten Malang. Mereka umumnya berdomisili di kecamatan yang menjadi kantong-kantong pengirim Tenaga Kerja Wanita (TKW) ke luar negeri, yaitu: Pagelaran, Tumpang, Kepanjen, Sumbermanjing Wetan, Tirtoyudo, Donomulyo, Dampit, Ampelgading, Bantur dan Gondanglegi. ${ }^{7}$ Kepala desa Tumpang, Kecamatan Tumpang Kabupaten Malang, Apriyono, juga membenarkan bahwa warganya banyak mengajukan gugat cerai karena suami yang berada di rumah dan ditinggal istrinya untuk bekerja ke luar negeri, berselingkuh dan bahkan menikah dengan wanita lain tanpa ada persetujuan dari istrinya. Kondisi seperti ini baru diketahui oleh istri, setelah pulang dari bekerja di luar negeri. Oleh karena itu, istri menggugat suaminya untuk bercerai.

Ada beberapa faktor penyebab perceraian di PA Kabupaten Malang yang ditengarai oleh Agus. ${ }^{8}$ Secara umum ada tiga macam, yaitu: masalah ekonomi, perselingkuhan dan kurang mampunya suami memberikan nafkah lahir dan batin. Namun, faktor yang paling dominan adalah faktor ekonomi dan perselingkuhan. Data dari Direktorat Jenderal Pembinaan Peradilan Agama Kementerian Agama juga menyatakan bahwa faktor ekonomi dan perselingkuhan telah menjadi penyebab perceraian keluarga nomor satu dan nomor empat. Lebih lanjut, Siti Romiyati menjelaskan bahwa gugatan cerai banyak diajukan oleh para TKW sepulang dari luar negeri karena mereka mengalami perubahan gaya hidup. Pengalaman dan hasil bekerja keras di luar negeri membuat mereka ingin tampil lebih modern dan modis. Begitu melihat sang suami masih bertahan pada penampilan ndeso (katrok), mereka tidak suka sehingga ingin berpisah. ${ }^{9}$

Rangkaian kasus perceraian tersebut juga bermuara pada rendahnya pendidikan dan Sumber Daya Manusia (SDM) yang dimiliki pasangan suami istri. Pasalnya, rata-rata pasangan suami istri (pasutri) yang menginginkan perceraian, pada saat menikah masih di bawah usia 17 tahun. Pada bulan Februari 2011 saja, surat permohonan cerai yang diterima sebanyak 593 kasus dan sudah diputus 495 kasus. Sedangkan kasus terbanyak adalah gugat cerai yang

6 Agus Azzam Aulia, Kabupaten Malang Peringkat Tertinggi Perceraian di Indonesia, Bhirawa. Diakses 18 Februari 2017.

${ }^{7}$ Ibid.

8 Agus Azzam Aulia adalah Wakil Panitera Pengadilan Agama Kabupaten Malang.

9 Agus Azzam Aulia, Kabupaten Malang Peringkat Tertinggi Perceraian di Indonesia, Bhirawa. Diakses 18 Februari 2017. 
dilayangkan oleh pihak istri sebanyak 387 gugatan, sisanya permohonan perceraian dari pihak suami. Pihak Pengadilan Agama tidak serta merta memutus cerai, melainkan tetap melihat semua kasus gugatan dan permohonan cerai terlebih dahulu. Pola seperti ini dilakukan dengan tujuan agar kedua belah pihak bisa mengajukan rujuk kembali dan menghindari perceraian. Dengan demikian, terdapat empat faktor yang tampak dominan mempengaruhi tingginya angka perceraian di PA Kabupaten Malang yaitu: faktor ekonomi, perselingkungan, pendidikan dan kawin usia muda.

Berangkat dari persoalan di atas, penulis tertarik untuk membahas tentang rekonstruksi makna perceraian dalam pemahaman masyarakat Muslim dengan mengambil lokasi di PA Kabupaten Malang dan Kecamatan Dampit yang menjadi kantong TKW ke luar negeri sekaligus yang mendominasi tingginya angka perceraian di Kabupaten Malang.

\section{Kasus Perceraian di Pengadilan Agama Kabupaten Malang}

Kasus perceraian di PA Kabupaten Malang tahun demi tahun mengalami peningkatan yang signifikan. Dari data PA Kabupaten Malang disebutkan bahwa angka perceraian tercatat sejak 2005-2006 berjumlah 2.747 perkara dan 2007 berjumlah 4.625 perkara. Pada tahun 2008 kasus perceraian sebanyak 2.145 perkara, sementara hingga bulan Desember 2009, menjadi 5.755 perkara. Artinya, hingga bulan Desember 2009, kasus perceraian tercatat mengalami peningkatan hingga 100 persen dibandingkan dengan tahun $2008 .{ }^{10} \mathrm{Di}$ sepanjang tahun 2010 di wilayah Jawa Timur, perceraian sebanyak 61.340 kasus yang terdiri dari 40.091 kasus cerai gugat dan 21.249 kasus cerai telak. Menurut Afnan Muhammidan, seorang hakim yang telah menyelesaikan perkara perceraian sebanyak 1.100 perkara pada tahun 2011 bahwa 70\% dari kasus perceraian adalah cerai gugat. Januari hingga Oktober 2012, tercatat 5.611 perkara dengan rincian Cerai Talak 1905 perkara dan Cerai Gugat 3706 perkara. Kasus perceraian yang demikian tinggi itu tersebar di seluruh daerah Kabupaten Malang dengan penduduk 2,5 juta jiwa lebih dari 33 kecamatan. Daerah. Yang angka perceraiannya tertinggi terletak di Malang Selatan. Di daerah ini mayoritas penduduknya terutama wanita bekerja sebagai TKW di luar negeri.

Dengan demikian, tingkat perceraian di Kabupaten Malang sangat tinggi. Bahkan berdasarkan catatan dari Kementerian Agama Jawa

${ }^{10}$ http://nasional.infogue.com/BERITA. Diakses 5 Desember 2015. 
Timur, Kabupaten Malang ini menjadi daerah yang menerima kasus perceraian terbanyak di Jawa Timur yaitu 7.479 kasus, disusul Kabupaten Banyuwangi dengan 6.794 kasus. Sementara Kota Surabaya menduduki urutan ketiga dengan 6.529 kasus perceraian. Selanjutnya Kabupaten Jember menempati urutan keempat dengan 5.798 kasus perceraian. Sedangkan terbanyak kelima adalah Kabupaten Blitar sebanyak 4.609 perkara. Pada setiap hari, terdapat 60 pasangan suami istri yang mengajukan gugat cerai di PA Kabupaten Malang, ${ }^{11}$ sehingga dalam satu bulan saja ada total 1.800 perkara. Sedangkan dalam satu tahun bisa mencapai 20 ribuan pasangan. Perkara perceraian di PA Kabupaten Malang setiap bulannya meningkat kecuali pada bulan Ramadan.

\section{Pemahaman Muslim di Kabupaten Malang terhadap Perceraian}

Dari pengumpulan data yang dilakukan di PA Kabupaten Malang dengan mewawancarai para hakim yang menyelesaikan perkara perceraian, diperoleh data bahwa istri yang menggugat cerai terhadap suami di PA Kabupaten Malang memahami bahwa perceraian merupakan hak istri sebagaimana halnya hak cerai talak yang dimiliki oleh suami. ${ }^{12}$ Pemahaman yang demikian menunjukkan bahwa istri semakin bertambah luas wawasannya tentang hak pengajuan gugatan perceraian. Luasnya wawasan istri tersebut diperoleh melalui kegiatan pengajian di media elektronik seperti TV. Pada awalnya, istri tersebut memahami bahwa hak perceraian hanya menjadi milik suami dan istri tidak berhak mengajukan gugatan perceraian karena istri hanya mengikuti suami. Tetapi dengan luasnya wawasan istri tentang hak perceraian maka begitu istri menghadapi masalah dengan suami, ia segera mengajukan gugatan perceraian.

Pemahaman istri bahwa gugatan perceraian menjadi hak istri dapat dibenarkan menurut peraturan perundang-undangan yang berlaku di Indonesia. Dalam Peraturan Pemerintah Nomor 9 tahun 1975 pasal 20 ayat (1) tentang Pelaksanaan UU Nomor 1 Tahun 1974 tentang Perkawinan ditegaskan bahwa gugatan perceraian diajukan oleh suami atau istri atau kuasanya kepada Pengadilan Agama yang daerah bukumnya meliputi tempat kediaman tergugat. ${ }^{13}$ Ketentuan ini sama dengan

11 http://wartabuana.com/daerah/Setiap-Hari-60-Pasutri-di-Malang-GugatCerai.html. Diakses 23 Februari 2017.

${ }^{12}$ Hakim Nur Ita Aini, Wawancara, Malang 21 Desember 2015.

13 Soemiyati, Hukum Perkawinan Islam dan Undang-Undang Perkawinan (UU Nomor 1 Tabun 1974, tentang perkawinan) (Yogyakarta: Liberty, 2004), 177. 
ketentuan yang terdapat dalam UU Nomor 7 tahun 1989 pasal 37 ayat (1) tentang Peradilan Agama. Namun, dalam Kompilasi Hukum Islam (KHI) pasal 132 ayat (1) terdapat sedikit perbedaan. Perbedaan tersebut terletak pada tidak adanya penyebutan kata "atau suami". Lebih tegasnya, pasal $132 \mathrm{KHI}$ ayat (1) menyatakan bahwa gugatan perceraian diajukan oleh istri atau kuasanya pada Pengadilan Agama, yang daerah bukumnya mewilayahi tempat tinggal penggugat kecuali istri meninggalkan tempat kediaman bersama tanpa iæin suami. ${ }^{14}$ Pemahaman istri tersebut boleh jadi karena kaum hawa semakin sadar dengan tuntutan kesetaraan dalam kehidupan berumah tangga. ${ }^{15}$

Dalam perkara perceraian yang lain yang diputuskan oleh Hakim Nur Ita Aini disebutkan bahwa istri terlalu mudah mengajukan gugatan perceraian ke PA Kabupaten Malang. Sikap ini diambil oleh istri karena kurangnya pemahaman terhadap ajaran agama dan/atau keimanannya tipis sehingga tidak takut akan balasan di akhirat. ${ }^{16}$ Secara spesifik, istri tersebut kurang mengetahui dan memahami makna perkawinan. Senada dengan persepsi Nur Ita Aini, A. Muzairi mengemukakan bahwa gugat cerai diajukan istri di PA Kabupaten Malang karena kurangnya pemahaman istri tentang perkawinan yang harus dipelihara agar kekal dan tidak berakhir dengan perceraian. Akibatnya, persoalan kecil pun dapat mendorong istri mengajukan cerai gugat di PA Kabupaten Malang. Demikian pula dengan persepsi hakim Afnan Muhammidan yang menyatakan bahwa istri terlalu mudah memutuskan sikap untuk bercerai. ${ }^{17}$

Menurut Afnan, istri yang menggugat cerai terhadap suami memahami perkawinan sebagai suatu kegiatan agar hubungan antara dirinya dengan laki-laki yang dicintainya menjadi halal. Namun dalam perkembangannya, perkawinannya kandas di tengah jalan di mana istri mengajukan gugat cerai terhadap suaminya. Sikap ini turut memberi kontribusi tingginya angka perceraian yang diajukan ke PA Kabupaten Malang. Dari data tersebut di atas diperoleh pemahaman bahwa istri terlalu mudah mengajukan gugatan perceraian karena kurangnya pengetahuan dan pemahaman istri tentang ajaran agama Islam serta hak dan kewajibannya (termasuk nafkah dan 'iddab).

14 Abdurrahman, Kompilasi Hukum Islam (Jakarta: Akademika Pressindo, 1995), 144.

15 Majalah Time (Asia's Divorce Boom, 5 April 2004)

16 A. Muzairi, Wawancara, Malang 21 November 2015.

17 Afnan Muhammi, Wawancara, Malang 21 November 2015. 
Dalam pandangan Islam, sebagaimana tersebut dalam KHI pasal (2) bahwa "perkawinan menurut hukum Islam adalah pernikahan, yaitu akad yang sangat kuat atau mithâqan ghalìdan untuk menaati perintah Allah dan melaksanakannya merupakan ibadah." Artinya, pasangan suami istri harus memahami bahwa perkawinan merupakan ibadah karena dilaksanakan untuk memenuhi perintah Allah dan Rasul-Nya. Beribadah dapat menjadikan setiap pasangan suami istri sadar bahwa dalam melangsungkan perkawinan itu tidak sekadar memenuhi keinginan hawa nafsu, kekayaan, ketampanan dan kecantikan belaka. Akan tetapi diniatkan untuk melaksanakan ibadah kepada Allah dan mengikuti tuntunan Rasulullah serta mencapai kebahagiaan yang hakiki. Dalam pasal (3) KHI juga dinyatakan bahwa "perkawinan bertujuan untuk mewujudkan kehidupan rumah tangga yang sakinah, mawaddah dan raḅmah" (tenteram cinta dan kasih sayang)."

Ada beberapa faktor yang menentukan keberhasilan terbentuknya keluarga sakinah sebagai tujuan perkawinan. Di antara faktor-faktor tersebut adalah faktor ibadah, sebagaimana tertulis dalam UndangUndang Nomor 1 Tahun 1974 tentang perkawinan pasal 1 bahwa "Perkawinan ialah ikatan lahir batin antara seorang pria dengan seorang wanita sebagai suami istri dengan tujuan membentuk keluarga (rumah tangga) yang bahagia dan kekal berdasarkan Ketuhanan Yang Maha Esa". Dengan ketentuan ini dapat dipahami bahwa tujuan perkawinan adalah terbentuknya keluarga (rumah tangga) yang bahagia dan kekal. Karena itu, maka Undang-Undang ini menganut prinsip untuk mempersulit terjadinya perceraian. Prinsip mempersulit perceraian sebagaimana dianut oleh Undang-Undang perkawinan dan Hukum Islam di atas didasarkan pada ketentuan hadith Nabi Muhammad yaitu: abghad al-halâl ilâ Allah al-talâq (perbuatan halal yang dibenci oleh Allah adalah talak). ${ }^{18}$ Prinsip mempersulit perceraian tersebut dimaksudkan agar tidak terjadi perpecahan antara dua keluarga besar masing-masing suami istri meskipun pada hakikatnya hubungan perkawinan suami istri itu bersifat antarpribadi.

Di samping karena kurangnya pemahaman istri tentang makna perkawinan yang menyebabkan istri terlalu mudah mengajukan gugat cerai, perceraian yang terjadi di PA Kabupaten Malang disebabkan juga karena ketidakpercayaan istri secara buta kepada suami. Jika suami dan istri sudah tidak memiliki rasa saling percaya, maka hanya

${ }^{18}$ HR. Abû Dâwud, Ibn Mâjah dan ṣaḥ̂ḥ menurut al-Ḥ̂akim. 
ada salah sangka di antara keduanya yang menyebabkan pertengkaran dan akhirnya mengganggu keharmonisan rumah tangga. Kondisi rumah tangga yang demikian tidak dibenarkan oleh Allah sebagimana dinyatakan oleh Allah dalam QS. al-Hujurât [49]: 12 yang artinya: wahai orang-orang beriman, jaubilah kebanyakan dari prasangka, sebab sesunggubnya syak wasangka adalah dosa. ${ }^{19}$ Dalam hal ini, suami istri harus saling percaya satu sama lain. Istri berkewajiban taat pada suami dan menjaga nama baik keluarga. Menjaga nama baik suami memiliki makna menjaga kehormatan istri sendiri. Istri harus menjauhkan diri dari mencampuri sesuatu yang dapat menyusahkan suami. Dengan cara demikian, diharapkan ketenteraman dan ketenangan dapat dicapai oleh pasangan suami istri yang akhirnya akan melahirkan kebahagiaan dalam berumah tangga. Sehingga, tujuan perkawinan tercapai sesuai dengan tuntunan agama yaitu keluarga yang sakinah, mawaddah dan rahmah. ${ }^{20}$ Inilah asas yang pertama dari Undang-Undang Perkawinan yakni asas membentuk keluarga yang bahagia dan kekal.

Faktor lain penyebab gugat cerai di PA Kabupaten Malang adalah karena rendahnya tingkat pendidikan istri (bagi kalangan kelas menengah ke bawah). Sedangkan pasangan suami istri yang berpendidikan tinggi bercerai karena pengaruh pihak ketiga. Tingkat pendidikan istri yang mengajukan gugat cerai paling banyak adalah Sekolah Menengah Tingkat Pertama (SMTP). Jumlah di bawahnya ditempati oleh istri yang tingkat pendidikannya SMTA atau setingkat dengannya. Sedangkan pasangan istri yang mengajukan gugatan perceraian dengan latar belakang pendidikan tinggi jumlahnya sedikit sekali.

Di kecamatan Dampit Malang, pendidikan masyarakatnya sangat rendah yang disebabkan oleh kemisikinan. Dengan kemiskinan dan pendidikan yang rendah kemudian menyebabkan penduduknya banyak yang memilih bekerja sebagai TKW ke luar negeri. Dengan rendahnya tingkat pendidikan tenaga kerja yang dikirim ke luar negeri dari Kecamatan Dampit baik laki-laki maupun perempuan memungkinkan mereka mudah terpengaruh oleh budaya dan gaya hidup luar negeri tempat mereka bekerja. Proposisi ini dapat dipahami karena dalam realitanya ada pengajuan gugatan cerai oleh istri

19 Departemen Agama RI, al-Quran dan Terjemahnya (Jakarta: PT. Bumi Restu, 1976/1977), 847.

20 Abdurrahman, Kompilasi Hukum Islam di Indonesia (Bandung: Humaniora Utama Press, 1991/1992), 18. 
terhadap suami di PA Kabupaten Malang karena perubahan gaya hidup istri setelah ia bekerja sebagai TKW di luar negeri. ${ }^{21}$ Perubahan gaya hidup tersebut tidak hanya pada segi mode, namun merambah hingga melakukan perselingkuhan dengan Pria Idaman Lain (PIL) atau lesbian di tempat mereka bekerja sebagai TKW di Hongkong. ${ }^{22}$

Tingkat pendidikan orang tua yang rendah di Kabupaten Malang menjadi penyebab kesadaran yang rendah terhadap pentingnya pendidikan bagi anak-anak mereka. Sehingga mengakibatkan tingginya angka pernikahan dini dan tak bersurat (nikah siri) dari kalangan anakanak yang tak lagi mengenyam pendidikan tersebut. Bagi mereka, isu pendidikan merupakan isu pinggiran. Belum terbentuk sebuah kesadaran sosial mengenai pentingnya pendidikan yang dibangun dalam mekanisme pengawasan belajar anak oleh kalangan dewasa yang dibangun secara sistematis, baik oleh masyarakat sekitar maupun oleh perangkat desa. Padahal, Kabupaten Malang merupakan daerah yang mengemban misi pendidikan. Bila dibandingkan dengan Yogyakarta, beberapa desa dan kampung di sana bahkan telah menetapkan jam belajar anak dan warga sebagai bentuk sistematis menanamkan kesadaran dan membangun budaya pendidikan dan belajar.

Faktor pendidikan merupakan faktor yang sangat penting dalam membentuk suatu keluarga yang sakinah (tenteram). Peran istri sebagai ibu dalam rumah tangga, pada hakikatnya memperkuat peran suami sebagai pemimpin keluarga. Latar belakang pendidikan yang dimiliki oleh pasangan suami istri tentu sangat mempengaruhi cara pandang, cara bersikap dan cara berpikir dalam menyelesaikan setiap persoalan dalam keluarga. Semakin luas wawasan atau semakin tinggi jenjang pendidikan suami istri, maka semakin dekat pula keluarga itu dengan tujuan perkawinan yakni keluaga yang tenteram. Berumah tangga tidak cukup dengan mengandalkan rasa kasih sayang dan tanggung jawab di antara mereka. Namun memerlukan wawasan ilmu pengetahuan untuk mengukuhkan hubungan suami istri dan kehidupan keluarga. Sebuah perkawinan ternyata tidak dapat dilaksanakan dengan insting belaka, tetapi perlu disertai dengan ilmu pengetahuan yang cukup. ${ }^{23}$

\footnotetext{
21 Afnan Muhammidan, Wawancara, Malang 21 November 2015.

22 Satinah, Wawancara, Malang 22 November 2015.

${ }^{23}$ Hasan Basri, Keluarga Sakinah: Tinjanan Psikologis dan Agama (Yogyakarta: Pustaka Pelajar, 1995), 88.
} 
Menurut hakim Nur Ita Aini, bahwa di PA Kabupaten Malang terdapat pengajuan gugatan cerai karena istri kecewa atas ketidakjujuran suami selama ditinggal kerja oleh istri sebagai TKW di luar negeri. Ketidakjujuran tersebut di antaranya dalam memegangi kesepakatan dengan istri selama istri bekerja sebagai TKW di luar negeri. ${ }^{24}$ Ketidakjujuran ini tercermin pada perilaku suami dalam penggunaan uang. Menurut Nur Ita Aini dan Afnan Muhammidan, suami menggunakan dana kiriman istri dari hasil kerja sebagai TKW di luar negeri bukan untuk membeli sesuatu yang sudah disepakati bersama antara suami dengan istri sebelum istri berangkat ke luar negeri sebagai TKW. Mereka bersepakat agar dana yang dikirimkan oleh istri pada suami di setiap bulannya digunakan untuk membangun rumah. Tetapi dalam kenyataannya, dana tersebut digunakan oleh suami untuk keperluan suami sendiri dan/atau untuk kepentingan yang tidak jelas.

Sikap ketidakjujuran suami selama ditinggal kerja oleh istri sebagai TKW Indonesia di luar negeri dilihat dari perspektif KHI jelas tidak benar. Menurut KHI pasal (80) bahwa suami adalah pembimbing terhadap istri dan rumah tangganya. Akan tetapi mengenai hal-hal urusan rumah tangga yang penting-penting diputuskan oleh suami istri bersama, sebagaimana disebutkan pada ayat (1). Selain itu, suami wajib melindungi istrinya dan memberikan segala sesuatu keperluan hidup berumah tangga sesuai dengan kemampuannya, hal ini disebutkan pada ayat (2). Lebih jauh lagi, suami wajib memberi pendidikan agama kepada istrinya dan memberi kesempatan belajar pengetahuan yang berguna dan bermanfaat bagi agama, nusa dan bangsa, disebut pada ayat (3). ${ }^{25}$ Dalam masalah ini, suami justru menunjukkan perilaku ketidakjujuran terhadap istri yang dilarang oleh ajaran agama Islam. Karena itu, perilaku suami ini tidak dibenarkan menurut hukum Islam dan peraturan perundang-undangan yang berlaku di Indonesia.

Senada dengan perkara gugatan cerai di atas adalah gugatan cerai yang diajukan oleh istri karena suami kurang atau tidak merespon kontribusi istri yang telah membantu mengerjakan tugas dan kewajiban suami dalam kehidupan rumah tangganya. Sebagaimana dinyatakan oleh Pansek A.Muzairi bahwa istri menggugat suaminya antara lain karena kurangnya perhatian suami terhadap istri karena

\footnotetext{
${ }^{24}$ Afnan Muhammidan, Wawancara, Malang 21 November 2015.

25 Abdurrahaman, Kompilasi, 132-133.
} 
suami sibuk bekerja untuk mengejar karir dalam pekerjaan. Dalam hal ini, menurut Nur Ita Aini, ${ }^{26}$ semua kewajiban suami seperti: a) mencuci pakaian suami dan anak-anak; b) menjaga kebersihan rumah dan lingkungan; serta c) mendidik anak telah dikerjakan oleh istri. Akan tetapi suami tidak atau kurang menghargai jerih payah istri. Sikap suami ini menyebabkan timbulnya kekesalan dan kemarahan istri terhadap suami yang pada gilirannya menimbulkan percekcokan antara istri dan suami yang berujung pada pengajuan gugatan cerai.

Sikap suami terhadap istri yang demikian menunjukkan bahwa suami tidak melaksanakan kewajibannya sebagai suami kepada istri. Sebagaimana diatur dalam KHI pasal 80 ayat (4) bahwa sesuai dengan penghasilannya suami menanggung: (a) nafkah, kiswah dan tempat kediaman bagi istri; (b) biaya rumah tangga, biaya perawatan dan biaya pengobatan bagi istri dan anak; (c) biaya pendidikan anak. Kewajiban suami terhadap istrinya seperti tersebut pada ayat (4) huruf (a) dan (b) di atas mulai berlaku sesudah ada tamkin sempurna dari istrinya. Semua itu menunjukkan bahwa istri tidak dalam keadaan nushûr, sehingga suami tetap berkewajiban melaksanakan semua tugas kewajiban tersebut. Memang dalam kenyataannya, istri telah menunjukkan sikap taat dan berbakti kepada suami lahir dan batin. Selain itu, istri juga telah menyelenggarakan dan mengatur keperluan rumah tangga sehari-hari dengan sebaik-baiknya. Lebih jauh, istri telah membantu dan mencapai kesejahteraan spiritual dan material. Karena itu, sikap istri yang mengajukan gugatan perceraian terhadap suami di PA Kabupaten Malang dapat dibenarkan jika dilihat dari fakta alasan yang ditemukan.

Pada kondisi di atas, suami dapat dikatakan telah melakukan

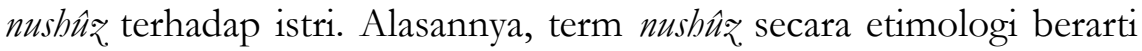
durhaka atau menentang. Sedangkan secara terminologi, nushûz adalah suami atau istri meninggalkan kewajiban. Nushûz bisa dilakukan oleh istri dan bisa pula dilakukan oleh suami. Istri yang melakukan nushîz. adalah istri yang tidak menjalankan salah satu dari kewajibankewajiban istri, sedangkan suami yang melakukan nushûz adalah suami yang tidak menjalankan salah satu dari kewajiban-kewajiban suami, sehingga istri kehilangan hak yang seharusnya ia peroleh dari suaminya. ${ }^{27}$

\footnotetext{
${ }^{26}$ Nur Ita Aini, Wawancara, Malang 21 November 2015.

${ }^{27}$ Nushûz suami adalah munculnya sikap acuh tak acuh dan penuh keangkuhan yang ditunjukakan suami terhadap istrinya, tidak mau menggaulinya, dan tidak bersedia
} 
Nushûz dalam Islam merupakan persoalan yang wajib diselesaikan dengan bijak, agar nushîz yang dilakukan oleh suami atau istri tidak berujung dengan perceraian. Apabila nushûz dilakukan oleh suami, maka istri harus bersikap proaktif mengambil prakarsa untuk memulihkan kondisi rumah tangga yang tidak harmonis melalui upaya-upaya damai sebagaimana dinyatakan oleh QS. al-Nisâ' [4]: 128. Upaya-upaya damai yang dapat dilakukan oleh istri terhadap suami yang nushâr. misalnya istri dengan kelembutan yang dimiliki dapat menyampaikan atau berbicara dari hati ke hati dengan suaminya untuk mengingatkan kekhilafan yang telah dilakukan oleh suaminya. Jika cara ini belum dapat menyelesaikan, maka istri bisa meminta bantuan pihak ketiga yaitu orang tua atau orang bijak yang dituakan oleh suami untuk menasehati agar suami dapat menunaikan kembali kewajibankewajiban sebagai suami dalam rumah tangganya.

Ada juga gugatan perceraian yang diajukan oleh istri terhadap suami di PA Kabupaten Malang karena istri kurang selektif ketika memilih dan menentukan calon suami. Calon istri tersebut tidak mampu mengidentifikasi perilaku suami dari sisi keagamaannya sejak dari awal sebelum keduanya menjadi pasangan suami istri. Misalnya, calon suami yang pemabuk dan/atau penjudi. Perilaku menjadi pemabuk dan/atau penjudi jelas kurang mendatangkan keuntungan dari segi materi. Suami kurang mengindahkan ketentuan agama seperti tidak mau mengerjakan salat, tidak berpuasa di bulan Ramadan dan suka meminum minuman yang memabukkan. ${ }^{28}$ Laki-laki seperti ini tetap dipilih oleh calon istri tersebut untuk dijadikan suami. Akibatnya, nafkah keluarga tidak/kurang tercukupi. Kondisi ini mendorong istri yang bekerja menjadi TKW di luar negeri menunjukkan kekesalannya. Kekesalan demi kekesalan mendorong pasangan suami istri itu bercekcok dan berselisih yang berujung pada pengajuan gugatan perceraian.

Kasus gugatan perceraian yang diajukan oleh istri karena kurang selektifnya dia dalam memilih dan menentukan calon suami terutama dari sisi perilaku beragamaannya menunjukkan bahwa kbiţbah kurang dipahami dengan benar oleh istri tersebut. Khitbah (peminangan)

untuk memberikannya nafkah lahir maupun batin. Boleh jadi keadaan ini muncul karena suami sudah sangat benci terhadap istrinya dan atau karena jatuh cinta pada perempuan lain. Wahbah al-Zuhaylî, al-Tafsîr al-Munir fì al-'A qîdah wa al-Sharî́ah wa al-Manhaj, Vol. 5 (Beirut: Dâr al-Fikr, t.th.), 291.

28 Afnan Muhammidan, Wawancara, Malang 21 November 2015. 
merupakan langkah pendahuluan menuju ke arah perjodohan antara seorang pria dan seorang wanita. ${ }^{29}$ Peminangan ini disyariatkan agar masing-masing calon mempelai dapat saling mengenal dan memahami pribadi mereka. Dengan melakukan khitbah, calon suami akan mengenal kepribadian wanita yang dipinang yang diharapkan menjadi istrinya kelak. Peminangan dapat langsung dilakukan oleh orang yang berkehendak mencari pasangan jodoh tapi dapat pula dilakukan oleh perantara yang dapat dipercaya, hal ini termaktub dalam pasal 11 di KHI. Peminangan dapat juga dilakukan secara terang-terangan (sarî̉) atau dengan sindiran (kinâyah). ${ }^{30}$ Dalam peminangan, laki-laki yang meminang dapat melihat wanita yang dipinangnya yang hukumnya sunah. Dengan melihat wanita yang dipinang itu, maka identitas maupun kepribadian wanita yang akan dikawininya itu dapat diketahui.

Dengan pengetahuan dan pengenalan yang benar tentang perilaku dan kepribadian laki-laki yang meminang diharapkan menimbulkan kesediaan dan persetujuan wanita untuk dijadikan istri tidak dengan cinta buta. Karena menurut KHI pasal 16 ayat (1) Perkawinan didasarkan atas persetujuan calon mempelai. Ayat (2) pasal ini juga menegaskan bahwa "bentuk persetujuan calon mempelai wanita dapat berupa pernyataan tegas dan nyata dengan tulisan, lisan atau isyarat tapi dapat juga berupa diam dalam arti selama tidak ada penolakan yang tegas". ${ }^{31}$ Dengan demikian, kemampuan wanita yang dipinang untuk memilih dan menentukan calon suami harus ditingkatkan agar identitas peminang yang diharapkan menjadi calon suami itu betulbetul teridentifikasi dengan benar dan baik.

Dengan demikian, persetujuan calon mempelai merupakan suatu hal yang penting yang dimaksudkan agar masing-masing suami dan istri memasuki gerbang perkawinan dan berumahtangga benar-benar dapat dengan senang hati membagi tugas, hak dan kewajibannya secara proporsional, sehingga tujuan perkawinan dapat tercapai. Menurut hemat penulis, persetujuan calon mempelai merupakan hasil dari peminangan (kbitbah) karena persetujuan tidak mungkin-atau setidak-tidaknya sulit—dilakukan apabila masing-masing calon tidak mengenal dan mengetahuinya. Dalam tahap awal, persetujuan dapat

\footnotetext{
${ }^{29}$ Sayyid Sâbiq, Fiqh al-Sunnah, Vol. 6 (t.t.: Maktabah al-Adab, t.th.), 51.

${ }^{30} \mathrm{Hal}$ ini diisyaratkan oleh QS. al-Baqarah [2]: 235, meskipun sesungguhnya konteks pembicaraannya tentang wanita yang ditinggal mati suaminya.

31 Abdurrahman, Kompilasi, 117.
} 
diketahui melalui wali calon mempelai wanita dan pada tahap akhir dilakukan petugas atau pegawai pencatat sebelum akad nikah dilangsungkan. Sebagaimana diatur dalam pasal $17 \mathrm{KHI}$, pengukuhan adanya persetujuan calon mempelai, maka Pegawai Pencatat Nikah (PPN) menanyakan kepada mereka. Pasal 17 KHI menegaskan: a) sebelum berlangsungnya perkawinan, PPN menanyakan lebih dahulu persetujuan calon mempelai di hadapan dua saksi nikah; b) bila ternyata perkawinan tidak disetujui oleh salah seorang calon mempelai, maka perkawinan itu tidak dapat dilangsungkan; dan c) bagi calon mempelai yang menderita tuna wicara atau tuna rungu persetujuan dapat dinyatakan dengan tulisan atau isyarat yang dapat dimengerti. ${ }^{32}$

Ketentuan KHI di atas dapat juga dipahami sebagai antitesis terhadap anggapan masyarakat bahwa kawin paksa, yakni wali memaksa anak perempuannya dikawinkan dengan laki-laki, masih dibenarkan. Padahal sebenarnya jauh-jauh hari Rasul telah memberi petunjuk dalam masalah ini sebagaimana diriwayatkan dari Ibn 'Abbâs: babwa Seorang gadis datang kepada Nabi SAW dan mengadu babwa bapaknya telah mengawinkannya (dengan seorang laki-laki sementara dia sendiri tidak suka karîab). Maka Rasul menganjurkannya untuk memilib". ${ }^{33}$ Menurut al-Ṣan'ânî bahwa hadîth tersebut menunjukkan haramnya pemaksaan ayah terhadap anaknya yang masih gadis untuk kawin. ${ }^{34}$ Akan tetapi al-Bayhaqî mendukung pendapat al-Shâfîi membolehkan seorang ayah memaksa kawin anak gadisnya apabila laki-laki calon suaminya sesuai (kufû). ${ }^{35}$ Namun, dalam konteks kehidupan sekarang komunikasi telah demikian longgar pendapat al-Shâfîî ini rasa-rasanya telah kehilangan relevansinya.

Ada pula gugatan perceraian yang diajukan istri terhadap suami di PA Kabupaten Malang karena istri tersebut tidak merasa takut akan bahaya akibat perceraian. Istri kurang memahami hukum Islam terkait dengan perceraian. ${ }^{36}$ Sikap istri yang menggugat suami untuk bercerai tersebut tampak ketika hakim memberikan arahan saat menyidang istri yang berperkara dengan mengatakan, apakah anda tidak merasa takut akan fitnah yang terjadi pascaperceraian, karena anda sudah tidak lagi

\footnotetext{
32 Ibid.

${ }^{33}$ HR. Aḥmad, Abû Dâwud dan Ibn Mâjah. al-Ṣanânî, Subul al-Salâm, Vol. 3, 122.

${ }^{34}$ Ibid.

${ }^{35} \mathrm{Ibid}$

36 Afnan Muhammidan, Wawancara, Malang 21 November 2012.
} 
bersuami? Perempuan tersebut tampak mempunyai tingkat emosi yang tinggi sehingga arahan yang diberikan oleh hakim kepadanya ketika melakukan persidangan perkara gugat cerai tampak kurang mendapatkan perhatian. Perempuan tersebut tampak nyata bersikap tidak takut akan bahaya perceraian. Perceraian dipandang bukan sesuatu hal yang ditakuti.

Sikap perempuan tersebut muncul karena kurang memahami bahaya perceraian. Ia juga tidak mengetahui bahwa perceraian merupakan perbuatan halal yang dibenci oleh Allah. ${ }^{37}$ Padahal sabda Rasulullah riwayat Ibn 'Umar menegaskan, perbuatan halal yang paling dibenci oleh Allah adalab talak (perceraian). ${ }^{38}$ Dari hadîth inilah kiranya umat Islam diajarkan agar menghindari perceraian agar terhindar dari kemurkaan dan kebencian Allah. Selain itu, hadîth inilah kiranya yang menjadi landasan asas untuk mempersulit terjadinya perceraian dianut oleh undang-undang perkawinan. Karena itu, perceraian hanya dapat dilakukan di depan sidang Pengadilan Agama setelah PA tersebut berusaha dan tidak berhasil mendamaikan kedua belah pihak. Untuk dapat mengajukan perceraian ke PA harus disertai dengan alasanalasan yang cukup sesuai dengan alasan-alasan yang telah ditentukan dalam Undang-Undang Perkawinan. Dengan asas ini diharapkan tujuan perkawinan untuk membentuk keluarga yang bahagia kekal dan sejahtera dapat tercapai.

Selain banyak faktor di atas, ada juga gugatan perceraian yang diajukan karena nafkah yang diberikan oleh suami terhadap istri tidak mencukupi kebutuhan keluarga. A. Muzairi, seorang Panitera Sekretaris PA Kabupaten Malang menggambarkannya dengan mengatakan, nafkah yang diberikan oleh suami tidak cukup untuk membeli susu anaknya. ${ }^{39}$ Perkara gugatan perceraian karena faktor ekonomi yang menurut Afnan Muhammidan, suami kurang dan/atau tidak bertanggung jawab atas kewajibannya sebagai suami dari segi ekonomi. ${ }^{40}$ Persoalan ekonomi yang mencukupi kebutuhan keluarga akan menambah kebahagiaan dan keharmonisan sebuah keluarga. Secara alamiah lakilaki harus bekerja di luar rumah untuk mendapatkan rejeki, mengorganisasikan urusan belanja buat keluarga agar mereka merasa nyaman hidup di rumah, meski tidak berlebihan. Harta kekayaan

37 Ibid.

${ }^{38}$ Ibid., 168.

39 A. Muzairi, Wawancara, Malang 21 November 2015.

${ }^{40}$ Afnan Muhammidan, Wawancara, Malang 21 November 2012. 
adalah jaminan hidup dan keputusan untuk pembelanjaan keluarga harus betul-betul diperhatikan oleh seorang suami sebagai kepala rumah tangga. ${ }^{41}$

Memberi nafkah menjadi kewajiban suami terhadap istri dan keluarganya sesuai dengan kemampuan suami serta keikhlasannya. Secara kondisional faktor inilah yang menjadi salah satu penyebab seorang suami ditempatkan sebagai seorang pemimpin dalam keluarganya sebagaimana yang dapat dipahami dari QS. al-Nisâ' [4]: 34. Nafkah yang menjadi kewajiban suami terhadap istri meliputi penyediaan segala macam keperluan istri, seperti makanan, pakaian, dan tempat tinggal. Kewajiban ini ditegaskan dalam QS. al-Baqarah [2]: 233 yang artinya: “...Ayah berkewajiban memberi makan dan pakaian kepada para ibu dengan cara yang patut. Seseorang tidak dibebani melainkan menurut kadar kemampuannya..." ${ }^{42}$ Agama menetapkan kewajiban kepada suami untuk memberi nafkah dengan syarat tidak ada hal-hal yang menyebabkan istri terhalang untuk menerimanya. Mengenai kadar nafkah, apabila suami tinggal bersama istri dan ingin memberi nafkah yang memenuhi kebutuhan istri, maka istri tidak berhak menuntut penentuan jumlah nafkahnya. Tetapi jika suami tidak memenuhi kebutuhan istri, maka istri boleh mengajukan besarnya kadar nafkah. Menurut ulama Hanafiyah, ${ }^{43}$ kadar nafkah tidak ditentukan oleh sharîah, tetapi suami wajib memenuhi kebutuhan istrinya yang meliputi makanan dan kebutuhan istri dalam kehidupan sehari-hari.

Islam menuntut agar kendali keluarga berada di tangan lelaki atau suami, karena kekuatan dan kelebihan yang telah dianugerahkan Allah kepadanya. Kepemimpinan bermakna menyerahkan manajemen dan urusan keluarga serta kemampuan untuk mengarahkan anggota keluarga kepada sesuatu yang baik. Pengertian ini menunjukkan bahwa bekerja keras dan mendorong untuk berbuat dan berjuang demi menafkahi keluarganya merupakan tanggungjawab suami. Walaupun demikian, istri juga dapat membantu suaminya demi terciptanya perekonomian keluarga dengan syarat mendapatkan persetujuan suaminya. Hal ini disebabkan karena suami istri samasama bertanggungjawab atas masa depan generasi yakni anak-anaknya, baik yang menyangkut kesejahteraan materi, maupun yang bersifat

\footnotetext{
41 al-Sabbagh, Keluarga Bahagia, 130

${ }^{42}$ Ibid., 57.

${ }^{43}$ Sâbiq, Fiqh, 87.
} 
immateri seperti kebutuhan intelektual, spiritual dan akhlak karimah. Jadi tanggungjawab tersebut harus dipikul oleh seluruh anggota keluarga. ${ }^{44}$ Jika istri memahami masalah ini, maka seyogyanya istri tidak mengajukan gugat cerai tetapi mencari jalan keluar agar kebutuhan ekonomi keluarganya dapat terpenuhi.

Gugatan cerai ada juga yang diajukan oleh istri terhadap suami karena istri mempunyai keyakinan akan mendapatkan ketenangan hidup (sakinah, mawaddah dan rahmah) pasca-perceraian. Keyakinan ini didorong oleh adanya keinginan kuat istri untuk mendapatkan suami yang menjanjikan hidup berbahagia, sakinah, mawaddah dan rahmah..$^{45}$ Keyakinan istri tersebut timbul karena ada faktor eksternal yakni pihak ketiga yang turut mempengaruhi. Gugatan perceraian karena pengaruh pihak ketiga lebih banyak diajukan oleh pasangan suami istri yang memiliki status kelas menengah ke atas. Pihak-pihak yang dapat dikategorikan sebagai pihak ketiga, menurut A. Muzairi ${ }^{46}$ adalah istriistri orang lain yang suka membicarakan perihal hubungan dirinya dengan suaminya masing-masing; suami melakukan kawin siri dengan wanita lain; suami berselingkuh dengan Wanita Idaman Lain (WIL) selama istri bekerja di luar negeri; intervensi keluarga dari pihak istri (ibu mertua suami); dan pengaruh advokat yang cenderung agar gugat cerai tetap dilangsungkan. ${ }^{47}$ Selain itu, ada juga istri yang mengajukan gugat cerai karena didorong oleh keinginannya mendapatkan harta bersama. Kecenderungan itu tampak meningkat terutama bagi pasangan yang memiliki harta.

Perkara-perkara gugatan perceraian yang terkahir ini menunjukkan bahwa istri yang mengajukan gugatan perceraian kurang memperhatikan akibat yang ditimbulkan oleh perceraian. Istri siap menanggung segala risiko yang diakibatkan oleh perceraian. Kesiapan ini dinyatakannya dengan tegas oleh istri. ${ }^{48}$ Maksud dan tujuan istri datang di PA Kabupaten Malang memang untuk mengajukan gugatan perceraian. Maksud dan tujuan istri tersebut tampak tidak bisa atau sulit didamaikan agar maksudnya diurungkan dengan mencabut pengajuan gugatan perceraian. Sulitnya pencabutan gugatan cerai itu

44 Istiadah Pembagian Kerja Rumah Tangga dalam Islam (Jakarta: Lembaga Kajian Agama dan Jender, Perserikatan Solidaritas Perempuan dan The Asia Foundation, 1999), 53.

45 A. Muzairi, Wawancara, Malang 21 November 2015.

46 Ibid.

${ }^{47}$ Afnan Muhammidan, Wawancara, Malang 21 November 2015.

${ }^{48}$ Ibid. 
karena mereka beralasan bahwa hati mereka sudah tidak mampu menahan keadaan yang menimpanya. Akibatnya, usaha mediasi yang dilakukan hakim atau mediator yang lain kepadanya tidak berhasil karena mereka datang ke PA Kabupaten. Malang bukan untuk meminta mediasi tetapi menggugat suami untuk bercerai sehingga tetap saja mereka bersikeras untuk bercerai dengan suami.

Menurut Afnan Muhammidan, ada juga perkara gugatan perceraian yang diajukan oleh istri sebagai akibat kekurangsiapan mereka melaksanakan perkawinan dengan keputusan Dispensasi Kawin (DK) karena calon suami belum berusia kawin (19 tahun) maupun karena calon istri belum juga mencapai usia kawin (16 tahun). Namun, Dispensasi Kawin lebih banyak diberikan kepada calon suami, artinya kepada kaum laki-laki yang banyak didominasi oleh kalangan laki-laki yang bekerja sebagai supir, buruh dan bengkel. Dispensasi Kawin diberikan kepada mereka karena calon istri sudah hamil sebelum menikah. Dalam kasus ini, mereka sudah melakukan hubungan seperti laiknya suami istri sehingga istri hamil sebelum nikah.

Dalam Undang-Undang No 1 tahun 1974 ayat (1) dinyatakan, "perkawinan hanya diizinkan jika pihak pria sudah mencapai umar 19 tahun dan pihak wanita mencapai umr 16 tahun". "Ketentuan batas umur ini seperti disebutkan dalam KHI pasal 15 ayat (1) didasarkan pada pertimbangan kemaslahatan keluarga dan rumah tangga perkawinan. Ini sejalan dengan prinsip yang diletakkan UU Perkawinan bahwa calon suami istri harus telah masak jiwa raganya agar dapat mewujudkan tujuan perkawinan secara baik tanpa berakhir pada perceraian dan mendapat keturunan yang baik dan sehat. Untuk itu harus dicegah adanya perkawinan antara calon suami istri yang masih di bawah umur.

Meskipun masalah penentuan umur dalam UU Perkawinan maupun dalam KHI bersifat ijtihâdîyah. Namun, apabila dilacak referensi sharî́ah-nya mempunyai landasan kuat, misalnya QS. alNisâ' [4]: 9. Ayat ini tidak langsung menunjukkan bahwa perkawinan yang dilakukan oleh pasangan usia muda (di bawah ketentuan yang diatur dalam UU No 1 tahun 1974) akan menghasilkan keturunan yang dikhawatirkan kesejahteraannya. Memang berdasarkan pengamatan berbagai pihak bahwa rendahnya usia kawin lebih banyak menimbulkan hal-hal yang tidak sejalan dengan misi dan tujuan

${ }^{49}$ Soemiyati, Hukum Perkawinan Islam, 141. 
perkawinan, yakni terwujudnya ketenteraman dalam rumah tangga berdasarkan kasih dan sayang.

Kasus perceraian yang disebabkan oleh kekurangsiapan pasangan suami istri ini sesungguhnya sudah diantisipasi dengan adanya ketentuan bahwa untuk kemaslahatan keluarga dan rumah tangga, perkawinan hanya boleh dilakukan calon mempelai pria yang telah mencapai umur sekurang-kurangnya 19 tahun dan wanita sekurangkurangnya 16 tahun. Sebagaimana dinyatakan dalam KHI pasal 15 ayat (1): "untuk kemaslahatan keluarga dan rumah tangga, perkawinan hanya boleh dilakukan calon mempelai yang telah mencapai umur yang ditetapkan dalam pasal 7 Undang-Undang No. 1 Tahun 1974 yakni calon suami sekurang-kurangnya berumur 19 tahun dan calon istri sekurang-kurangnya berumur 16 tahun". ${ }^{50}$ Undang-Undang Perkawinan Nomor 1 Tahun 1974 dan Kompilasi Hukum Islam tampak menganut prinsip bahwa calon suami istri harus telah masak jiwa raganya untuk dapat melangsungkan perkawinan. Dispensasi Kawin yang diberikan kepada mereka yang belum masak jiwa raganya besar kemungkinan akan mengakibatkan mereka berpikir pada perceraian bukan berpikir bagaimana agar perkawinannya dapat mendatangkan kebahagiaan yang kekal. Padahal jika kematangan jiwa dan raga pasangan suami istri telah terpenuhi akan dapat memudahkan mereka mewujudkan tujuan perkawinan secara baik tanpa berpikir pada perceraian dan mendapat keturunan yang baik dan sehat.

Kasus gugatan perceraian yang lain diajukan oleh istri di PA Kabupaten Malang karena adanya kekerasan dalam Rumah Tangga $\left(\right.$ KDRT ${ }^{51}$ seperti istri dipukuli oleh suami, suami tidak mempunyai kepedulian terhadap istri dan anaknya, tidak melaksanakan kewajibannya sebagai suami terhadap istri dan anaknya. Akibatnya terjadi ketidakharmonisan hubungan suami istri dalam rumah tangga mereka. Sebagai contoh, suami ringan tangan sehingga istri mengajukan gugatan perceraian agar segera terbebas dari belenggu hubungan mencekam dengan suaminya. Padahal suami mempunyai kewajiban non materiil terhadap istri misalnya memperlakukan istri

\footnotetext{
50 Abdurrahman, Kompilasi, 117.

${ }^{51}$ Kekerasan dalam rumah tangga yang penulis maksud adalah setiap tindakan yang mengakibatkan kesengsaraan dan penderitaan bagi perempuan baik secara psikologis, fisik dan seksual termasuk tindakan tertentu, pemaksaan atau perampasan kemerdekaan secara sewenang-wenang baik yang terjadi di depan umum atau dalam lingkungan pribadi.
} 
secara sopan, memperhatikan secara penuh, membimbing, tidak memaksanya bekerja keras untuk urusan rumah tangga, kesetiaan suami dan keterbukaan suami. ${ }^{52}$

Seorang suami wajib menghormati dan menghargai hak-hak istrinya. Hal ini sesuai dengan penegasan QS. al-Nisâ' [4]: 19 yang artinya: "...dan bergaullah dengan mereka (istri-istrimu) secara patut..." Ayat ini menegaskan bahwa seorang suami dilarang memperlakukan istrinya dengan sikap yang kasar tanpa memperhatikan dan menghargai haknya sebagai istri. Sesungguhnya perintah ini bukan hanya berlaku pada suami terhadap istrinya, sebaliknya seorang istri juga wajib bersikap yang sama terhadap suaminya. Dengan perkataan lain, usaha membentuk keluarga sakinah memerlukan suasana saling menghargai antara suami dan istri agar ikatan suci yang telah terjalin di antara keduanya tetap baik tidak ternodai oleh perilaku yang semena-mena.

Dari uraian di atas, dapat dikatakan bahwa pemahaman pasangan suami istri terhadap perceraian yang diajukan di PA Kabupaten Malang adalah kurang. Kurangnya pemahaman mereka tersebut disebabkan karena kurangnya pemahaman terhadap ajaran Islam terutama mengenai makna perkawinan dan bahaya perceraian dengan segala konsekuensinya. Di antara mereka ada yang menganggap perceraian sebagai suatu hal biasa. Ada juga pasangan suami istri yang menganggap bahwa perceraian merupakan satu-satunya jalan untuk mengakhiri perkawinan.

\section{Akibat Perceraian bagi Muslim di Kabupaten Malang}

Perceraian membawa akibat yang tidak ringan bagi janda atau duda pasca-perceraian. Menurut Plamer dan Koch-Hattem, dalam kondisi terbaik sekalipun perceraian adalah pengalaman yang sangat mengganggu secara emosional. Bercerai menimbulkan berbagai konsekuensi dan risiko yang tidak ringan terutama bagi wanita. Seorang wanita setelah bercerai dari suami akan dihadapkan pada serangkaian permasalahan. Pertama, masalah keuangan janda yang mengalami perceraian dan tidak menikah lagi mengalami $50 \%$ penurunan pendapatan rumah tangga. Kedua, masalah status perempuan akan mendapat status baru yaitu janda. Status ini dapat membawa masalah tersendiri karena stigma janda masih berkonotasi negatif, khususnya di Indonesia. Selain stigma negatif, perempuan

\footnotetext{
52 Abidin, Fiqh, 171.

${ }^{53}$ Departemen Agama RI., al-Qur'an dan Terjemahnya, 119
} 
juga harus berhadapan dengan pandangan sosial karena dianggap sebagai istri yang gagal membina keluarga. Ketiga, peran ganda perempuan sebagai ibu sekaligus ayah bagi anak. Keempat, masalah tempat tinggal setelah bercerai akan terjadi perubahan tempat tinggal, antara lain kembali ke rumah orang tua, tinggal bersama anggota keluarga lain, atau tetap bertahan di rumahnya. Kelima, masalah penyesuaian ulang ke masyarakat. ${ }^{54}$

Oleh karena itu, meskipun perkawinan dalam Islam merupakan ibadah dan mîthâq ghalìd (perjanjian suci), namun apabila perkawinan putus atau terjadi perceraian maka urusan tidak begitu saja selesai. Ada akibat-akibat hukum yang perlu diperhatikan oleh pasangan suami istri yang bercerai. Akibat-akibat hukum tersebut bukan hanya disebabkan karena perceraian, namun kematian salah satu pihak juga memiliki konsekuensi hukum tersendiri. Dengan akibat hukum tersebut, perceraian di PA Kabupaten Malang juga menimbulkan akibat terhadap kehidupan ekonomi mantan suami istri yang bercerai.

Dalam Ketentuan Undang-Undang Nomor 1 Tahun 1974 tentang perkawinan pasal 41 dinyatakan bahwa: baik ibu atau bapak tetap berkewajiban memelihara dan mendidik anak-anaknya, semata-mata berdasarkan kepentingan anak-anak, bilamana ada perselisihan mengenai penguasaan anak-anak pengadilan memberi keputusannya; bapak yang bertanggung jawab atas semua biaya pemeliharaan dan pendidikan yang diperlukan anak itu; bilamana bapak dalam kenyataan tidak dapat memenuhi kewajiban tersebut, Pengadilan dapat menentukan bahwa ibu ikut memikul biaya tersebut; pengadilan dapat mewajibkan kepada bekas suami untuk memberikan biaya penghidupan dan/atau menentukan sesuatu kewajiban bagi bekas istrinya..$^{55}$

Akibat hukum perceraian dalam ketentuan pasal 41 UUP tersebut tampak masih bersifat global. Rincian ketentuan tentang akibat hukum perceraian ini diatur dalam KHI yang dirinci menjadi empat kategori yaitu: akibat cerai talak, cerai gugat, akibat khulú' dan akibat li'ân. Akibat yang terakhir dan yang tidak mendapat penekanan khusus adalah akibat kematian suami. Dalam konteks ini penulis hanya

\footnotetext{
54 Retno, "Perbedaan Penyesuaian Sosial Pasca Perceraian antara Wanita Bekerja dan Wanita Tidak Bekerja" (Skripsi--Fakultas Psikologi Universitas Muhammadiyah Surakarta, 2010), 19.

${ }^{55}$ Soemiyati, Hukum Perkawinan Islam, 140-150.
} 
mengemukakan akibat hukum putusnya perkawinan karena perceraian talak dan perceraian gugat saja mengingat dua hal inilah yang terkait.

Dalam KHI pasal 149 ditegaskan bahwa bilamana perkawinan putus karena talak maka bekas suaminya berkewajiban: a) memberikan mut'ah yang layak kepada bekas istrinya baik berupa uang atau benda, kecuali bekas istri tersebut qabl al-dukhûl; b) memberi nafkah, maskan dan kiswah (tempat tinggal dan pakaian, pen) kepada bekas istri selama

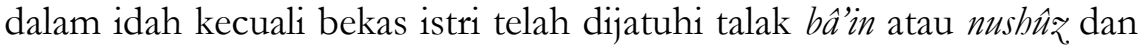
dalam keadaan tidak hamil; c) melunasi mahar yang masih terhutang seluruhnya dan separuh apabila qabl al-dukhûl; dan d) memberikan biaya hadânah (pemeliharaan termasuk di dalamnya biaya pendidikan, pen) untuk anak yang belum mencapai umur 21 tahun.

Rujukan dari ketentuan tersebut di atas adalah QS. al-Baqarah [2]: 233, 236 dan 237. Bagi istri yang ditalak raj’̂, suami berhak merujuknya selama dalam masa idah. Ketentuan tentang masa idah ada dalam KHI pasal 150. Dasarnya adalah QS. al-Talâq [65]: 1. Bekas istri selama dalam masa idah, menurut pasal $151 \mathrm{KHI}$, wajib menjaga dirinya, tidak menerima peminangan dan tidak menikah dengan pria lain. Karena pada hakikatnya, istri dalam masa idah masih dalam ikatan nikah dengan suaminya. Terhadap wanita yang berada dalam peminangan orang lain saja dilarang untuk meminangnya apalagi terhadap wanita yang masih berada dalam masa tunggu. Karena itu, suamilah yang paling berhak untuk merujuknya. Dalam hal ini, Nabi menegaskan, janganlah seseorang dari kamu meminang (wanita) yang dipinang saudaranya, hingga peminang sebelumnya meninggalkannya atau telah mengizinkannya.

Dari uraian tentang kewajiban bekas suami terhadap bekas istri pascacerai talak sebagaimana tersebut di atas jelas bahwa ketentuan tersebut berkaitan erat dengan masalah ekonomi. Memang masalah ekonomi menjadi sesuatu yang urgen dalam kehidupan keluarga. Persoalan ekonomi yang mencukupi kebutuhan keluarga akan menambah kebahagiaan dan keharmonisan sebuah keluarga. Harta kekayaan adalah jaminan hidup dan keputusan untuk pembelanjaan keluarga yang harus diperhatikan oleh seorang suami sebagai kepala rumah tangga. Sebaliknya, persoalan ekonomi juga merupakan salah satu faktor yang sangat dominan dalam terjadinya perselisihan dan perceraian. Suami istri sering cekcok gara-gara tidak memilki uang yang cukup untuk kebutuhan yang harus dipenuhi. 
Ketika istri tersebut masih mempunyai suami saja kebutuhan keluarganya tidak mampu dipenuhi oleh nafkah yang diberikan oleh suami kepada istrinya sehingga istri tersebut mengajukan gugatan perceraian terhadap suami. Logis jika dikatakan bahwa bekas istri tersebut akan semakin berat untuk mampu memenuhi kebutuhan diri dan anaknya karena pasca-perceraian berarti seorang istri berstatus sebagai single parent. Ia memikul tugasnya sendiri sebagai kepala rumah tangga sekaligus sebagai ibu rumah tangga. Pada masa sekarang ini, single parent adalah salah satu fenomena yang banyak dijumpai dalam masyarakat yakni keberadaan orang tua tunggal. Ia mengasuh dan membesarkan anak-anaknya sendiri tanpa bantuan dari pasangannya. Sepertinya tak mudah untuk menyandang status ini di tengah-tengah masyarakat yang masih memandang sebelah mata akan keberadaan single parent. Belum lagi ia harus menerima cap negatif dari lingkungannya.

Apabila status single parent itu adalah bekas istri maka ia menjalankan peran ganda yakni peran sebagai single parent dan peran sebagai ibu rumah tangga. Sebagai seorang single parent, ia harus mampu mengkombinasikan dengan baik antara pekerjaan domestik dan publik. Apabila ia berada di tempat kerja, maka ia harus mengkonsentrasikan diri sepenuhnya pada pekerjaannya. Sebaliknya, apabila ia telah berada di rumah, maka ia harus ia harus menjalankan peran untuk kebelangsungan hidup keluarganya. Ia harus mencurahkan seluruh perhatiannya terutama pada anaknya, juga makan, belajar, atau pun membacakan dongeng sebelum tidur. Oleh karena itu, kematangan fisik dan psikologis janda merupakan faktor yang sangat vital dibutuhkan untuk melakukan menajemen keluarga agar dapat melaksanakan tugas-tugas tersebut secara efisien dan efektif seperti tugas membesarkan dan mendidik anak-anaknya. Alasannya karena, kematangan pada wanita single parent dapat mempengaruhi caranya dalam mengatur diri dan keluarganya, terutama dalam bentuk karakter anak.

Wanita yang menjadi janda mengalami permasalahan ekonomi, terutama jika saat menikah tidak bekerja dan hanya mengandalkan penghasilan dari suami. Jika tiba-tiba kehilangan suami yang selama ini menopang perekonomian keluarga para janda pun tidak memiliki pemasukan tetap. Wanita-wanita yang menjadi janda sering dihadapkan pada kesulitan ekonomi karena tanggung jawab wanita tersebut menjadi bertambah dengan harus menjadi seorang ibu 
sekaligus menjadi tulang punggung keluarga untuk membiayai anakanaknya. ${ }^{56}$

Melihat banyaknya permasalahan yang dialami oleh wanita dengan status janda seperti yang telah disebutkan di atas, akhirnya banyak dari para janda mengalami kesulitan dalam menjalani kehidupanya. Tingkat kesejahteran para janda mengalami penurunan karena kesiapan janda dalam mengatasi masalah dalam kehidupannya yang masih rendah. Kondisi tersebut dipengaruhi oleh tingkat ekonomi yang semakin tinggi dan tingkat survival para janda yang masih rendah. ${ }^{57}$ Tingkat kesejahteran janda yang memprihatinkan, karena kurangnya perhatian dari masyarakat dan tingkat survival serta tingkat pendidikan untuk bertahan hidup yang rendah. Faktor ekonomi menjadi salah satu masalah yang sulit ditangani oleh para janda. Kondisi setelah perceraian ataupun ditinggalkan suami memiliki beban psikologi yang berat bagi para janda. Para janda yang sebelumnya menggantungkan pemasukan keluarga dari suami sekarang harus bekerja sendiri. Pandangan wanita bekerja di kalangan masyarakat yang masih tabu membuat wanita jarang yang bekerja dan hanya menjadi ibu rumah tangga.

Kondisi janda yang memperihatinkan di atas mengakibatkan para janda mengambil jalan pintas untuk memenuhi kehidupannya. Tekanan yang dihadapi para janda membuat mereka memilih untuk melakukan tindakan kriminal atau kehidupan menyimpang. Terkadang para janda terlibat pada kehidupan prostitusi ataupun pencurian dan penjualan narkoba. Contoh kasus yang terjadi di Malang seorang janda ditangkap karena kedapatan menjual narkoba jenis sabu-sabu. Perilaku negatif tersebut dilakukan tidak lain karena untuk mencari uang demi pemenuhan kebutuhan dirinya dan anak-anaknya. Tidak hanya para janda yang mengalami dampak buruk, tetapi anak-anaknya juga terkena dampaknya.

Sebagaimana diketahui, keluarga merupakan tempat individu untuk mendapatkan suatu pembelajaran utama. Dalam hal ini, keluarga harus dapat mendidik keturunannya menjadi makhluk sosial yang berguna dalam masyarakat. Kepribadian seseorang berpengaruh besar terhadap pendidikan keluarga. Oleh karena itu peran orang tua selain mengurus dan memperhatikan anak-anak juga harus memiliki pengetahuan agar dapat mengkoordinir dan mensosialisasikan hal-hal

\footnotetext{
${ }^{56}$ Retno, "Perbedaan Penyesuaian Sosial", 13-15.

${ }^{57}$ Jawapos, Edisi 29 Januari 2011.
} 
yang baik terutama untuk anak. Sosialisasi merupakan bentuk pembelajaran sosial karena fungsi sosialisasi menunjuk pada peranan keluarga dalam bentuk kepribadian anak. Proses sosialisasi tidak sewajarnya diberikan kepada orang lain. Peran orang tua dalam proses sosialisasi menjadi peran utama dan sangat penting, oleh karena anak akan meniru segala yang dilihat dan diajarkan oleh orang tuanya.

Masyarakat sangat menggantungkan diri kepada keluarga dalam hal sosialisasi sebagai tahapan untuk memasuki usia dewasa agar anak dapat berperan positif di tengah-tengah masyarakat. Hal ini sesuai dengan pandangan Gertrude Jeager yang menyatakan bahwa peran sosialisasi dari orang tua sangat penting, sang anak bergantung pada apa yang terjadi pada orang tuanya. Pelaksanaan fungsi sosialisasi yang mendasar adalah karena di dalam sebuah keluarga, nilai-nilai dan norma-norma serta aturan-aturan yang berlaku dalam masyarakat diwariskan pada individu dalam sebuah keluarga. Melalui proses sosialisasi inilah seorang anak dibentuk oleh orang tuanya agar anak menjadi bertanggung jawab sehingga terbentuklah kepribadiannya dan menjadikan anak yang mandiri dalam menghadapi persoalan hidup. Dalam suatu keluarga, melalui proses sosialisasi setiap anak atau individu belajar berinteraksi dengan sesamanya seperti orang tua, kakak, paman, bibi, nenek, kakek, dan sebagainya. ${ }^{58}$

Suatu sistem sosial merupakan keseluruhan dari kompleksitas unsur-unsur budaya yang saling berhubungan satu dengan yang lain dalam suatu kesatuan yang utuh dan terpadu. Menurut Parson, bahwa di dalam setiap masyarakat senantiasa terdapat tujuan-tujuan dan prinsip-prinsip dasar tertentu yang dianggap dan diterima oleh sebagian besar anggota masyarakat sebagai suatu hal yang mutlak. Sistem nilai tersebut tidak saja merupakan sumber yang menyebabkan berkembangnya integrasi sosial, akan tetapi sekaligus merupakan unsur stabilisasi sistem sosial budaya itu sendiri. ${ }^{59}$ Di samping itu, sistem sosial memiliki dua tingkatan yang berbeda. Pertama, sistem sosial yang dapat dianggap sebagai struktur sosial interaktif konkret, misalnya sebuah keluarga. Kedua, sistem sosial yang dapat dipandang sebagai sebuah unit yang lebih abstrak atau sebuah unit di mana polapola antar-hubungannya berlaku dari generasi ke generasi dan dari daerah ke daerah.

\footnotetext{
58 Susi Evi Susanti, "Perkawinan di Usia Muda di Desa Pulau Panjang" (Skripsi-Prodi Sosiologi, Fakultas Ilmu Sosial dan Politik Universitas Riau, 2009), 75.

${ }^{59}$ Ibid., 63.
} 
Dalam hal ini, status janda sebagai single mother karena telah bercerai dengan suaminya, justru menghambat dirinya untuk bersosialisasi dengan masyarakat sekitar. Hal ini disebabkan oleh adanya tekanan dari lingkungan sekitar akan status sebagai single mother yang disandang. Selain itu kesibukan akan pekerjaan juga menjadi faktor kurangnya dia bersosialisasi. Karena itu, dia cenderung mengandalkan orang yang berada di lingkungan keluarga untuk melaksanakan fungsi keluaga serta memberikan penanaman nilai-nilai dan norma-norma pada anak. Hal ini dikarenakan selain responden yang kebanyakan tinggal dengan kerabat keluarga lainnya (orang tua, kakak, karib kerabat), juga karena responden bisa bersosialisasi dengan lingkungan sekitar.

Secara psikologis, keluarga dapat memberikan hubungan sosial yang penuh dengan kemesraan, cinta kasih, kasih sayang dan kebahagiaan. Fungsi afeksi ini sangat penting bagi perkembangan pribadi anak. ${ }^{60}$ Alasannya karena hal ini merupakan kebutuhan dasar manusia. Para psikiatris berpendapat bahwa penyebab utama gangguan emosional, masalah prilaku dan gangguan fisik pada anak adalah ketiadaan cinta kasih yakni tidak adanya kehangatan hubungan kasih sayang dalam lingkungan asosiasi yang intim. Wujud kasih sayang yang diberikan oleh orang tua single parent kepada anak-anaknya dalam kegiatan yang dilakukan bersama-sama seperti shalat berjama'ah akan membentuk psikologis anak. Misalnya lagi, anak mendapatkan pujian jika ia melakukan perbuatan terpuji dan berguna. Sebaliknya ia mendapatkan teguran jika ia melakukan kesalahan dan kenakalan. Bagi anak yang masih kecil atau yang berada di bawah usia sekolah, fungsi afeksi dilakukan dengan cara membangunkannya tiap pagi, bermain dengannya, membuatkan mainannya atau pergi jalanjalan.

Selanjutnya, fungsi yang diemban oleh keluarga adalah fungsi proteksi. Yaitu, fungsi yang berhubungan dengan segala kebutuhan fisik anak yang mana semuanya bernilai praktis dan juga termasuk dalam hal perawatan anak. Salah satu fungsi keluarga adalah perlindungan. Fungsi perlindungan dapat dibagi tiga, yaitu perlindungan fisik, ekonomi, dan psikologis. Setiap anggota keluarga pasti membutuhkan ketiga hal tersebut. Sorang bayi yang baru lahir memulai hidupnya dengan perlindungan penuh karena ia tidak mempunyai kemampuan dan kekuatan untuk melakukan sesuatu. Bayi

${ }^{60}$ Khairuddin, Sosiologi Keluarga (Yogyakarta: Nurcahaya, 1985), 205. 
tanpa perlindungan orang tua dan keluarga sudah tentu tidak akan hidup lama. Fungsi proteksi juga mencakup tentang bagaimana orang tua dapat mengontrol dan mengawasi kegiatan-kegiatan yang dilakukan oleh anak, baik di dalam maupun di luar rumah. Selain itu, kebutuhan anak yang bernilai praktis di sini contohnya adalah peran orang tua (ayah dan ibu) dalam hal perawatan diri anak, kerapian dan kebersihannya, memperhatikan semua kegiatan yang dilakukan setiap hari, mengingatkan waktu belajar, bekerja dan beristirahat, diskusi timbal balik dan melindungi anak dari rasa kurang aman atau ketakutan.

Aspek psikologis seorang janda begitu mendalam, terlebih lagi ada stigma negatif bahwa janda harus berhadapan dengan pandangan sosial karena dianggap sebagai istri yang gagal membina keluarga. Memang, permasalahan yang dialami wanita yang hidup menjanda sangat kompleks. Pertama, harus membesarkan anak-anaknya seorang diri. Hal ini tidaklah mudah karena bagaimana pun juga anak-anak yang sedang tumbuh dan mencari identitas diri akan membutuhkan figur ayah. Bagi anak laki-laki, figur seorang ayah sangat dibutuhkan karena selama proses identifikasi, seorang anak laki-laki biasanya meniru kebiasaan orang-orang terdekat yang dianggap mempunyai kelebihan untuk ditiru, dan biasanya proses identifikasi ini merujuk pada sosok ayah. Bagi seorang janda, untuk menciptakan figur ayah yang dapat dijadikan contoh bagi anak-anaknya, khususnya anak lakilaki, tentu bukanlah hal yang mudah. Jika persoalan ini tidak diatasi dengan baik oleh ibu-ibu janda, bukan tidak mungkin akan menimbulkan krisis identitas pada anak.

Sedangkan secara sosial, masyarakat umumnya masih memandang status janda dengan pandangan negatif. Sebutan janda, tanpa memandang peringkat kelas sosial, adalah aib. Beragam stigma ditimpakan kepadanya oleh masyarakat yang menganggap tempat perempuan yang terbaik adalah di samping suami. Janda mengalami beban sosial ditimpakan oleh masyarakat, tanpa pernah mau melihat berbagai faktor penyebab atau kondisi perempuan menjanda, masyarakat cenderung menghakimi dan memberi label buruk serta kejam kepada para janda. Kedudukan janda di masyarakat memiliki perbedaan berdasarkan stigma yang ditimpakan oleh masyarakat pada setiap janda. Janda karena ditinggal mati suaminya memiliki kedudukan stigma baik dibandingkan dengan janda karena perceraian. 
Janda perceraian dianggap sebagai seseorang penuh masalah. ${ }^{61}$ Kondisi inilah yang membuat beberapa janda perceraian mengalami tekanan dalam masyarakat dan sulit untuk bangkit memperbaiki kehidupanya.

Pascaperceraian, wanita perlu melakukan penyesuaian sosial terhadap situasi baru yang dihadapi yakni berubahnya status pernikahan dari bersuami menjadi janda. Pandangan masyarakat tentang wanita yang cerai cenderung bersifat negatif, misalnya wanita dianggap tidak mampu sebagai ibu rumah tangga, wanita dianggap telah melakukan kesalahan saat berumah tangga. Perceraian mengakibatkan aktivitas dan kehidupan sehari-hari para janda dapat terganggu. Kebanyakan janda yang tidak bisa melakukan penyesuaian kembali kehidupanya setelah perceraian mengalami perilaku menyimpang seperti mencuri, narkoba, prostitusi dan bahkan yang tidak sanggup mengatasi tekanan dalam hidupnya memilih untuk bunuh diri seperti kasus di Lampung pada bulan april 2010, seorang janda nekat bunuh diri karena terlilit utang dan kesulitan memenuhi kebutuhan hidupnya. ${ }^{62}$ Masalah ekonomi merupakan faktor utama dalam setiap kesejahteran janda. Kondisi tersebut diperparah dengan minimnya perhatian masyarakat terhadap janda.

Wanita yang sudah bercerai membutuhkan dukungan sosial dari keluarga dan masyarakat untuk menghadapi segala permasalahan. Dengan kata lain wanita yang sudah bercerai membutuhkan dukungan dari keluarga yang ada di sekitarnya untuk membantu mengatasi permasalahan-permasalahan yang dihadapi dan menghadapi tuntutantuntutan lingkungan sosial. ${ }^{63}$ Dukungan sosial yang diberikan dapat membantu melakukan penyesuaian yang lebih baik terhadap lingkungan sosialnya dan membantu menghadapi berbagai tuntutan di masa selanjutnya perlu mendapat perhatian segala pihak. Wanita yang bercerai dan bekerja, serta yang tidak bekerja akan berpengaruh terhadap penyesuaian sosialnya. ${ }^{64}$ Wanita yang bercerai dan bekerja dapat menyesuaikan dirinya dengan lingkungan karena terbawa oleh kebiasaan sosialnya di tempat kerja yang membantu proses penyesuaian sosial wanita pasca bercerai. Wanita bercerai yang tidak

${ }^{61}$ Fachrina, "Pandangan Masyarakat terhadap Perceraian: Studi Kasus Cerai Gugat dalam Masyarakat Minangkabau Kontemporer" (Laporan Penelitian Forum HEDS, Jakarta, 2005), 13.

62 www.poskota.co.id/berita. Diakses tanggal 25 Februari 2017.

${ }^{63}$ Retno, "Perbedaan Penyesuaian Sosial ", 4.

${ }^{64}$ Ibid., 6. 
bekerja mengalami kesulitan dalam penyesuaian diri karena sudah terbiasa dengan kehidupan di lingkungan keluarga. Penyesuaian sosial wanita pasca perceraian pada wanita yang bekerja dikatakan lebih berhasil dibandingkan dengan wanita setelah perceraian yang tidak bekerja.

\section{Penutup}

Perceraian yang terjadi di Pengadilan Agama Kabupaten Malang disebabkan oleh faktor-faktor yang bervariasi dengan penyebab terbesar yaitu ketidak harmonisan, yang disusul oleh faktor tidak ada tanggung jawab, intervensi pihak ketiga, ekonomi, kekerasan dalam rumah tangga, kawin paksa dan krisis akhlak/moral. Dalam hal perceraian, masyarakat Islam di Kabupaten Malang memahaminya sebagai jalan keluar bahkan "satu-satunya" jalan bagi konflik yang dihadapi oleh pasangan suami istri. Ada pula yang memahami perceraian sebagai suatu hal yang biasa sehingga tidak ada rasa takut dan malu di dalam diri mereka terhadap risiko yang akan dtimbulkan. Pemahaman tersebut timbul karena kurangnya pengetahuan akan makna perkawinan dan bahaya perceraian dengan segala konsekuensinya. Perkawinan bukan sebagai kontrak sosial biasa, atau bukan perjanjian untung rugi yang sewaktu-waktu boleh dibatalkan oleh kedua belah pihak tetapi sebagai ikatan luhur, sakral dan suci serta merupakan ikatan perjanjian yang kokoh dan agung, bukan hanya sebagai ikatan perdata melainkan sebagai perikatan keagamaan.

\section{Daftar Rujukan}

\section{A. Buku}

Abdurrahman. Kompilasi Hukum Islam. Jakarta: Akademika Pressindo, 1995.

-----. Kompilasi Hukum Islam di Indonesia. Bandung: Humaniora Utama Press, 1991/1992.

Departemen Agama RI, al-Qur'an dan Terjemabnya. Jakarta: PT. Bumi Restu, 1976/1977.

Fachrina. "Pandangan Masyarakat terhadap Perceraian: Studi Kasus Cerai Gugat dalam Masyarakat Minangkabau Kontemporer". Laporan Penelitian Forum HEDS, Jakarta, 2005.

Hadikusuma, Hilman. Hukum Perkawinan Indonesia Menurut Perundangan, Hukum Adat, Hukum Agama Hindu-Islam. Bandung: Mandar Maju, 1990.

Basri, Hasan. Keluarga Sakinah: Tinjauan Psikologis dan Agama. Yogyakarta: Pustaka Pelajar, 1995. 
http:// www.surabayapost.co.id. Diakses tanggal 20 Februari 2017. http://nasional.infogue.com/berita. Diakses 5 Desember 2015.

Istiadah. Pembagian Kerja Rumah Tangga dalam Islam. Jakarta: Lembaga Kajian Agama dan Jender, Perserikatan Solidaritas Perempuan dan The Asia Foundation, 1999.

Khairuddin. Sosiologi Keluarga. Yogyakarta: Nurcahaya, 1985

Retno. "Perbedaan Penyesuaian Sosial Pasca Perceraian antara Wanita

Bekerja dan Wanita Tidak Bekerja". Skripsi--Fakultas Psikologi Universitas Muhammadiyah Surakarta, 2010.

Rofiq, Ahmad. Hukum Islam di Indonesia. Jakarta: PT.Raja Grafindo Persada, 1995.

Șan'ânî (al), Muḥammad b. Ismâ'îl b. Ṣalâh b. Muḥammad al-Ḥusaynî al-Kaḥlânî. Subul al-Salâm, Vol. 3. Kairo: Dâr Ihyầ' al-Turath al'Arabî, 1960.

Sâbiq, Sayyid. Fiqh al-Sunnah, Vol. 6. t.t.: Maktabah al-Adab, t.th.

Sekar, Ayuningtyas dkk. Perceraian: Makalah Psikologi Seks dan Perkawinan. Surakarta: Universitas Sebelas Maret, t.th.

Soemiyati, Hukum Perkawinan Islam dan UU Perkawinan: Undang-Undang Nomor 1 Tabun 1974 tentang Perkawinan. Yogyakarta: Liberty, 2004.

Susanti, Susi Evi. "Perkawinan di Usia Muda di Desa Pulau Panjang". Skripsi-- Prodi Sosiologi, Fakultas Ilmu Sosial dan Politik Universitas Riau, 2009.

Zuhaylî (al), Wahbah. al-Tafsîr al-Munir fî al-'Aqîdah wa al-Sharî́ah wa alManhaj, Vol. 5. Beirut: Dâr al-Fikr, t.th.

\section{B. Wawancara}

Aini, Nur Ita. Wawancara. Malang 21 November 2015.

----. Wawancara. Malang 21 Desember 2015.

Muhammidan, Afnan. Wawancara. Malang 21 November 2012.

Muzairi, A. Wawancara. Malang 21 November 2015.

Satinah. Wawancara. Malang 22 November 2015. 